\title{
Chemical denudation rates of a small torrential catchment in the Northern Calcareous Alps
}

\author{
Georg TROST ${ }^{* *}$, Jörg ROBL ${ }^{2)}$, Sylke HILBERG ${ }^{2)}$, Christoph HAUZENBERGER ${ }^{3)}$, Rudolf SCHMIDT ${ }^{4)}$ \& Walter GOESSLER ${ }^{5)}$ \\ 1) Department of Geoinformatics, University of Salzburg, Hellbrunnerstraße 34, 5020 Salzburg, Austria; \\ 2) Department of Geography and Geology, University of Salzburg, Hellbrunnerstraße 34, 5020 Salzburg, Austria; \\ 3) Institute of Earth Sciences, University of Graz, Universitätsplatz 2, 8020 Graz, Austria; \\ 4) Austrian Service for Torrent and Avalanche Control, Section Salzburg, Bergheimer Straße 57, 5021 Salzburg, Austria; \\ 5) Institute of Chemistry, University of Graz, Universitätsplatz 1, 8010 Graz, Austria; \\ *) Corresponding author: georg.trost@sbg.ac.at
}

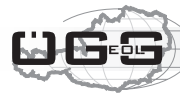

KEYWORDS

denudation rates; Northern Calcareous Alps; mass balance; chemical denudation

\begin{abstract}
In this study, we present chemical denudation rates derived from measuring the dissolved load of an alpine catchment located in Salzburg, Austria. The catchment has a drainage area of about $7 \mathrm{~km}^{2}$ and is predominantly covered by limestone-rich glacial deposits and carbonate rocks that are characteristic of the Northern Calcareous Alps. To obtain catchment-wide chemical denudation rates, we integrated discharge time series that were measured by a permanent water gauge of the Austrian Service for Torrent and Avalanche Control to compute the total discharge of the investigated catchment over a period of one year. During the same period, samples were taken during several campaigns to consider variations of the dissolved load. Samples were collected at high and low runoff conditions to study the effect of precipitation and at different locations along the tributaries to account for lithological variations of the river beds on the dissolved load.

For the investigation period of one year, $2.97 \times 10^{6} \mathrm{~m}^{3}$ of discharge was measured at the catchment outlet. The summed cation-concentration varies between about $85 \mathrm{mg} / \mathrm{l}$ for dry-conditions and $75 \mathrm{mg} / \mathrm{l}$ for rainy-conditions at the gauge and consists predominantly of $\mathrm{Ca}^{2+}$ and $\mathrm{Mg}^{2+}$ cations. Based on the total discharge of the river integrated over a period of one year, and the average dissolved load determined from water samples, we obtained a chemical denudation rate of $0.094 \mathrm{~mm} / \mathrm{a}$. The results imply that chemical denudation is a significant driver for redistributing mass in carbonatedominated catchments and might be the dominant erosional process in such settings.
\end{abstract}

\section{Introduction}

Our understanding of the decay of alpine landscapes and the pace of landscape adjustment to climatic or tectonic changes relies on catchment-wide erosion rates, which are generally determined by quantifying the concentration of cosmogenic nuclides such as ${ }^{10} \mathrm{Be}$ (Wittmann et al., 2007; Norton et al., 2011). Quartz-bearing bedrocks are a prerequisite of this standard approach, making this method inapplicable for carbonatedominated catchments of the Northern Calcareous Alps (NCA). Hence, data on catchment-wide erosion rates for this large domain of the Alps are rare. Several studies highlight the importance of dissolved sediment load with regard to the total sediment flux from elevated topography towards stable base levels (e.g. Hay, 1998; Hinderer et al., 2013). In carbonate-dominated catchments, the importance of dissolution is even more pronounced, as the dissolved load may account for $90 \%$ of the total sediment flux in alpine rivers (Morche and Schmidt, 2012). As a result of intense karstification, large areas of the NCA are drained by subsurface flow, implying that mechanical erosion becomes less important than chemical erosion. Moreover, the total topography plays an important role. In gently sloping areas, the influence of chemical denudation is even higher than in areas with steep slopes or

in flatland regions (Hay, 1998). In this type of geological setting, the dissolution of rocks may represent the dominant process for the redistribution of mass and the decay of alpine topography over the time scale of millions of years. Hence, quantifying the annual amount of dissolved load, transported by rivers and torrents draining the NCA, allows catchment-wide erosion rates to be estimated in regions not suitable for cosmogenic nuclide dating.

The quantification of chemical weathering in carbonate dominated catchments has been tackled by several studies for more than 50 years. Trudgill (1975) suggests directly measuring the weight loss and determining the mass deficit of limestone tablets exposed to rain or soil water (High and Hanna, 1970). Cucchi et al. (2006) measured elevation changes of the river bed due to dissolution by using a "micro-erosion meter" over different periods of time, while Stone et al. (1998) determined catchment-wide erosion rates by measuring the concentration of cosmogenic ${ }^{36} \mathrm{Cl}$ - a method similar to the widely employed ${ }^{10}$ Be approach (Wittmann et al., 2007). The simplest and probably most elegant method was applied by Corbel (1959), who determined the dissolved load in rivers by multiplying the discharge of the river with the ion concentration of the water. With the availability of robust 
hydrochemical data, it is possible to calculate a denudation rate and highlight the spatial inhomogeneity related to the predominant lithology of even small catchments.

This pilot study aims to quantify the annual amount of dissolved load routed along an alpine torrent in the NCA and follows the approach of Corbel (1959) by combining discharge time series and hydrochemical data.

\section{Characterization of the study region}

In this study, we investigate the annual amount of dissolved load of the Schwarzaubach catchment, upstream of the village Ebenau, which is located about $20 \mathrm{~km}$ east of Salzburg (Fig. 1). At Ebenau, a permanent gauging station of the Austrian Torrent and Avalanche Control records the water level of the Schwarzaubach in 15-minute intervals (Fig. 2, 3C). Downstream of Ebenau, the Schwarzaubach drains towards the south and confluences with the Almbach representing a major tributary of the Salzach River. The outlet point of the investigated catchment is located at about $600 \mathrm{~m}$ (gauging station: $619 \mathrm{~m}$ ), and the highest peaks slightly exceed 1200 m (Lidaun Peak: $1237 \mathrm{~m}$ ) resulting in an elevation difference of ca. $600 \mathrm{~m}$. The Schwarzaubach drainage system encompasses a contributing drainage area of $6.97 \mathrm{~km}^{2}$ and consists of three important subcatchments: the Ellmaubach catchment
$\left(A=2.24 \mathrm{~km}^{2}\right)$, the Siederbach catchment $\left(A=0.79 \mathrm{~km}^{2}\right)$ and the Katzenbach catchment $\left(A=0.5 \mathrm{~km}^{2}\right)$ (Fig. 1). The annual precipitation of the study area amounts to about $1600 \mathrm{~mm} \mathrm{y}^{-1}$, as measured by the precipitation gauge at Hintersee, Flachgau (771 m).

The Schwarzaubach catchment is located in the NCA, and bedrocks consist predominantly of Upper Triassic (Hauptdolomit) to Cretaceous (Oberalm Formation) carbonates (Fig. 2). The study region was significantly overprinted during the Pleistocene glaciation cycles, resulting in the occurrence of glacial landforms and unconsolidated sediments (Egger and van Husen, 2009). Rocks of the NCA appear at the topographically highest parts and act as the northeastern and southwestern watershed of the catchment. The stratigraphically lowest unit of the study area, the Upper Triassic Hauptdolomit (Norian), is well-bedded with a high joint density and characterized by gray dolomitic limestone deposited in a shallow-marine environment (Egger and van Husen, 2009) (Fig. 2, 3D). The highest peaks of the catchment consist of Hauptdolomit. Stratigraphically higher units such as the upper Upper Triassic Dachsteinkalk (Norian-Rhaetian) unit as well as the Upper Jurassic to Lower Cretaceous Oberalm Formation (Tithonian-Berriasian) and the Upper Cretaceous Kreuzgraben Formation (Turonian) are only

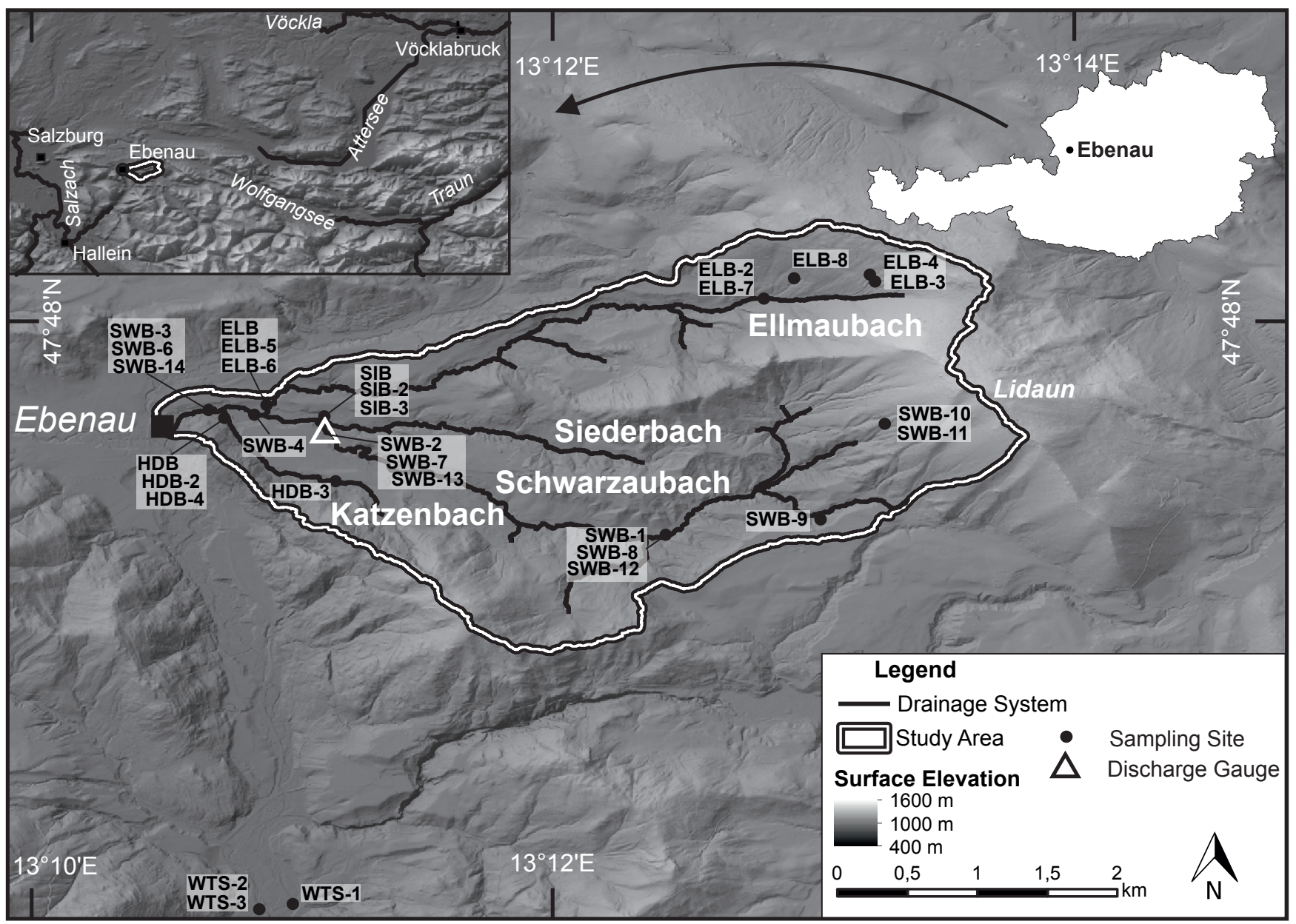

Figure 1: Geographical overview of the study area east of Salzburg and the sampling locations. Samples were taken during the hydrochemical measurement campaigns (compare Tab. 1-3). 
present in the northeastern part of the catchment area. The Dachsteinkalk is characterized by decimeter-scale bedding and tends to be less jointed than the Hauptdolomit. The Dachsteinkalk is a shallow-marine limestone containing diverse types of megalodonts (Egger and van Husen, 2009). The stratigraphically highest Oberalm- and Kreuzgraben formations rarely occur and are separated from the Dachsteinkalk by a brittle fault (Fig. 2). The Kreuzgraben Formation consists of poorly sorted conglomerates made up of calcareous alpine rock fragments (Egger and van Husen, 2009). These can be found redistributed in the streambed of the Ellmaubach. The Kreuzgraben Formation transgressively overlies the Oberalm Formation, which is characterized by light grey, fine layered micritic limestones.

Large areas, especially the lowland domains at the western part of the study area and valley infills, are characterized by Pleistocene glacial and proglacial deposits (Kame terrace, Fig. 2, 3A, 3B). The glacially sculpted landscape is dominated by ice wastage features such as local deltas, hummocky moraines or isolated kames. Additionally, typical features like kettle holes are formed during the melting of dead ice fields (Salcher et al., 2010) (Fig. 2).
Pleistocene sediments of the study region are intercalated deltaic foreset and bottomset sediments deposited as kame terraces in the setting of temporarily proglacial lakes. The petrographic composition of the gravels is dominated by carbonates of the NCA and a smaller amount of crystalline pebbles from the central Eastern Alps (Egger and van Husen, 2009). The bedding of the sediments is divided into sandy gravel-layers and sand-layers with thicknesses between 50 and $80 \mathrm{~cm}$, and clay-layers of up to $5-10 \mathrm{~cm}$ (Fig. 3A). These clay-layers act as less permeable aquitards and are therefore of outstanding hydrological importance (Egger and van Husen, 2009) (Fig. 3F). Recent surface processes at hillslopes and channels are documented by hillslope and torrential deposits, as well as alluvial fans.

\section{Methods}

\subsection{Materials}

The basis of the hydrogeological investigations is a digital elevation model (DEM) with a resolution of $1 \times 1 \mathrm{~m}$. The LIDAR-DEM was provided by the state government of Salzburg (Sagis, 2014). During a nationwide monitoring
439500

441000

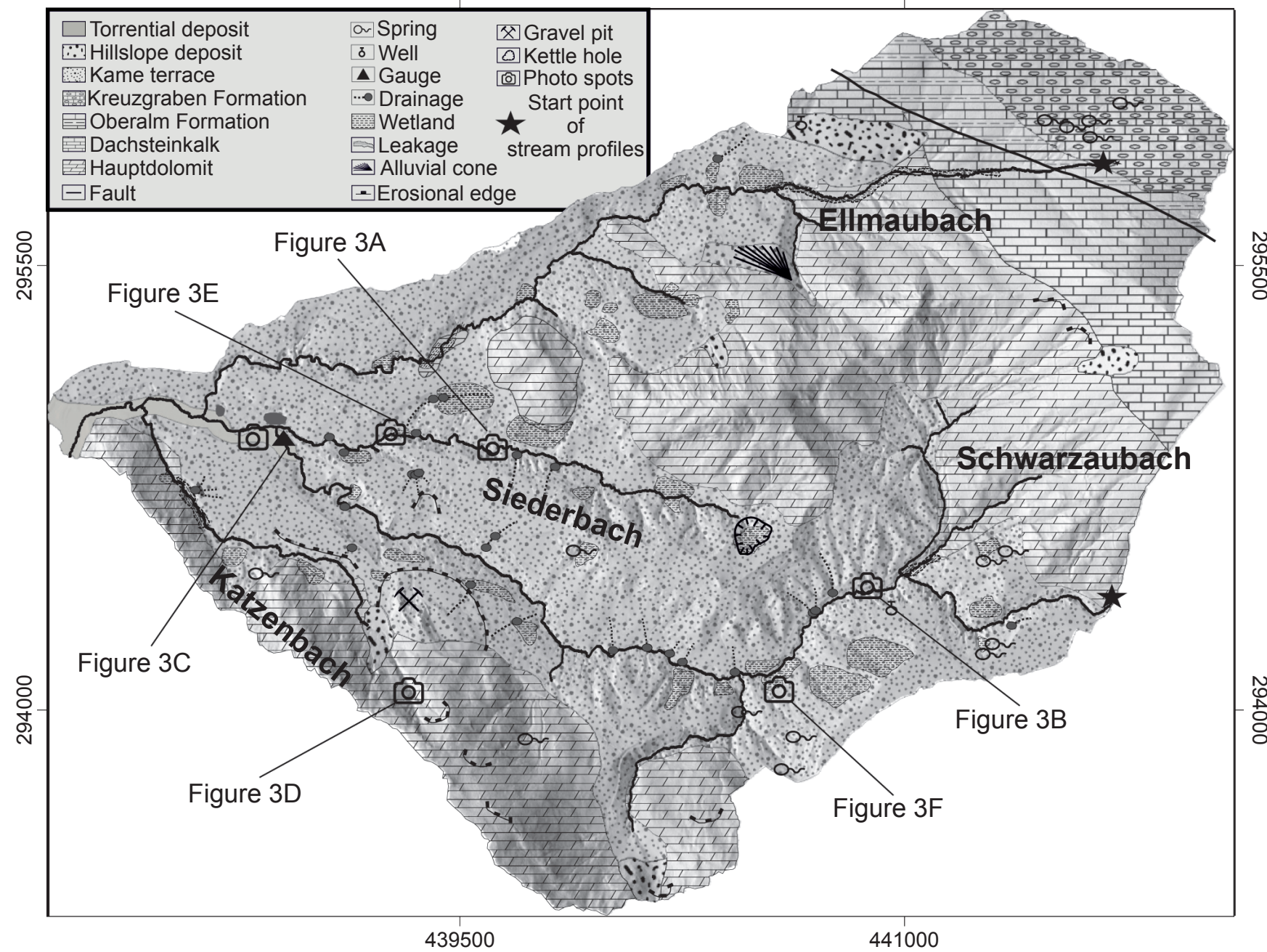

Figure 2: Geological and hydrogeological map of the study area. Camera symbols show locations of photographs shown in Figure 3. 

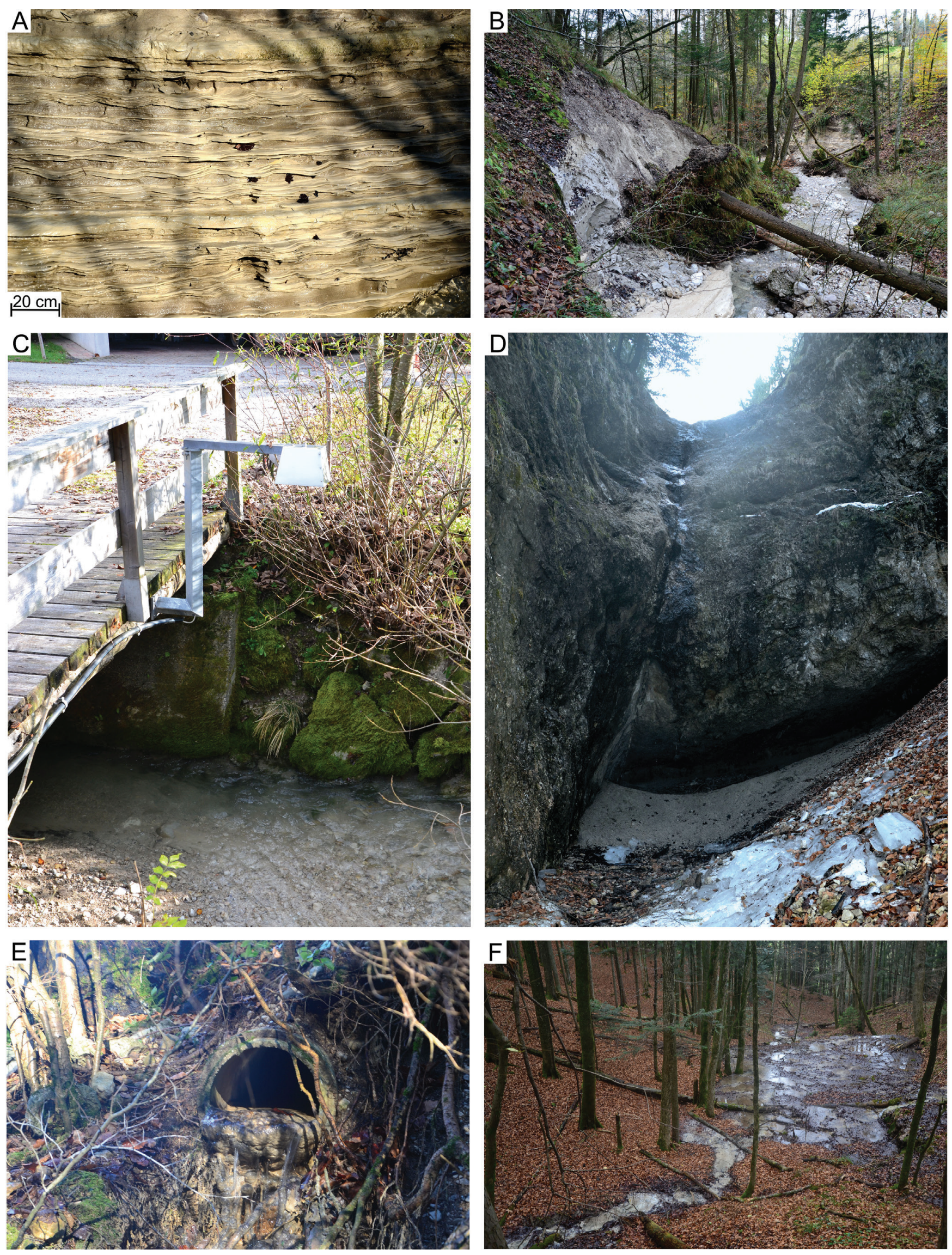

Figure 3: Intercalated clay layers (A); Stream cutting through glacial deposits (B); Discharge gauge at the Schwarzaubach River (C); Incised bedrock channel at the Katzenbach River (D); Calc-sinter deposits in a drainage pipe (E); Wetland zone caused by clay layers in a forest (F); All detailed positions of the photographs are tagged on Figure 2. 
program, the Austrian Torrent and Avalanche Control equipped a number of torrents with automatic gauging stations that record the water level every 15 minutes. The high temporal resolution of this dataset allows the annual discharge to be determined even of small torrents that are characterized by large and rapid discharge fluctuations. The gauge of the Schwarzaubach is located about $500 \mathrm{~m}$ downstream of a storage reservoir (Fig. 3C). The evaluation period is determined to be from $1^{\text {st }}$ September 2013 to $1^{\text {st }}$ September 2014 in order to achieve a discharge period of exactly one year. The Zentralanstalt für Meteorologie und Geodynamik (ZAMG, 2017) reports higher precipitation values from September to December 2013 (Station Salzburg-Airport) and lower precipitation values from January to August 2014 in comparison to the longterm average. The measured temperature increased by $0.4^{\circ} \mathrm{C}$ in 2013 and by $1.6^{\circ} \mathrm{C}$ in 2014 , which was one of the warmest years ever recorded. The positive temperature anomaly is especially dominant during the evaluation period (Station Salzburg-Airport).

\subsection{Hydrogeological characterization of the drainage basin}

For the characterization of the drainage basin, a GISbased analysis and an extraction of the sub-basins are performed. A flow direction raster and a flow accumulation raster are calculated using the D8-Algorithm (O'Callaghan and Mark, 1984). The flow accumulation and flow direction maps enable the delineation of the watersheds. Here, we follow the standard approach implemented in GRASS-GIS (Neteler et al., 2012). We extracted longitudinal channel profiles from the high resolution DEM to characterize the geometric properties of the torrents (e.g. Robl et al., 2008).

We performed a hydrogeological field campaign based on the geological map sheet GK50 Strasswalchen (Egger and van Husen, 2009) and the hydrological GIS-based analysis of this study. We focused on the mapping of springs, wetlands and seepage locations of the streams and on taking water samples at several locations along the streams (Fig. 1). The sampling includes the measurement of in-situ parameters like temperature, specific electric conductivity and $\mathrm{pH}$-values. Additionally, we measured conductivity profiles for the Schwarzaubach and Ellmaubach during fair weather and rainy weather-dominated runoff conditions to show the influence of varying discharge regimes and the impact of tributaries on the dissolved load along the main streams of the catchment.

\subsection{Evaluation of the gauge time series}

The automated gauging station features a radar measurement of the water level. For the calculation of mass balances, we have computed the discharge of the Schwarzaubach from the level data by applying the salt dilution method (Rantz, 1982). The resulting values of the salt dilution measurement were then correlated to the automated gauging station and extrapolated to the whole range of the level height timeseries. In order to achieve a satisfying measuring range, we repeated the discharge measurement at varying water levels and weather conditions. In total, four measurements were performed with the Logotronic QTRACE-Discharge Measuring system. To compensate for the rather small amount of data points, we performed three of the measurements during a single rainfall event. One measurement was performed at an increasing water level, one measurement at a decreasing water level and the last measurement at low water conditions after the event. The fourth measurement was performed independently from the rainfall event and represents low runoff conditions.

\subsection{Measurement of the cation concentration}

Catchment-wide denudation rates are computed by the quantification of the cation concentration of water sampled in channels. Therefore, three series of measurements were carried out during varying weather conditions along the stream profiles. To demonstrate different hydrochemical processes, e.g. karst-related in the aquifers, we sampled the cation concentrations of all streams and compared the effects of varying water levels and precipitation conditions. $50 \mathrm{ml}$ water was collected in a precleaned polypropylene vial directly taken from a clean vessel. One $\mathrm{ml}$ of double distilled $\mathrm{HNO}_{3}$ was added immediately after sampling. At the same time, several in-situ parameters were measured from the running waters. The samples were analyzed with an Agilent 7500 ICP-MS (inductively coupled plasma mass spectrometry) at the Institute of Chemistry, University of Graz. The concentrations of the following elements were determined: $\mathrm{Mg}$, $\mathrm{Ca}, \mathrm{Na}, \mathrm{K}, \mathrm{Ba}, \mathrm{Fe}, \mathrm{U}, \mathrm{Rb}, \mathrm{Li}, \mathrm{Mn}, \mathrm{Pb}$ and Cs. The timespan between sampling and ICP-MS-measurement amounted to a maximum of two months. The accuracy of the results was evaluated with the NIST CRM 1640a "trace elements in water". The results obtained were in good agreement with the certified concentrations.

\subsection{Mass balancing of denudation rates through hydrochemical measurements}

The calculation of denudation rates depends on the dissolved amount of rock material. The continuous recording of discharge at the gauge allows the application of a rather simple method for the calculation of chemical denudation rates averaged over an alpine catchment. The approach is based on the concentration $C(\mathrm{mg} / \mathrm{l})$, the discharge $Q(\mathrm{I})$ over the desired timespan $t(\mathrm{~s})$, the catchment area $A\left(\mathrm{~km}^{2}\right)$ and the rock density $\rho\left(\mathrm{kg} / \mathrm{m}^{3}\right)$ (Bakalowicz, 1979; Gunn, 1981; Lauritzen, 1990; Plan, 2005; Gabrovšek, 2009). In order to distinguish between stormflow and baseflow, a separation of the total flow is performed by applying the local minimum method, which checks for the lowest discharge value in a specific interval and thus detects local minima (Pettyjohn and Henning, 1979). The baseflow discharge is used to calculate denudation rates based on cation concentrations 
of samples obtained during baseflow-dominated runoff conditions. Vice versa, cation concentrations of samples obtained during stormflow conditions and the stormflow runoff are used to compute denudation rates characteristic for a stormflow runoff regime. The annual denudation rate is the sum of both flow regimes. Subsequently, we compared the annual denudation rate to a rate obtained from the product of the mean cation concentration of all samples and the total discharge.

Only the $\mathrm{Ca}^{2+}$ - and $\mathrm{Mg}^{2+}$-ions are considered for the computation of the denudation rates. These two ions arise from weathering of carbonate rocks and are the largest portion of the dissolved load. Neither the geological map nor our field campaign gave evidence for the occurrence of sulphate-bearing minerals (as a source of $\left(\mathrm{a}^{2+}\right)$ in the drainage basin. The total dissolved amount of $\mathrm{CaCO}_{3}$ and $\mathrm{MgCO}_{3}$ can be calculated from the $\mathrm{Ca}^{2+}$ - and $\mathrm{Mg}^{2+}$-concentrations. We determine the catchment-wide chemical denudation rate $\mathrm{D}(\mathrm{m} / \mathrm{a})$ as a function of time $t$ by the addition of $\mathrm{CaCO}_{3}$ and $\mathrm{MgCO}_{3}$ and subsequent application of equation 1:

$$
D=\frac{1}{t . A . \rho} \int_{t_{0}}^{t} Q(t) C(t) d t
$$

We suppose that the average density of carbonates in the study area is $2700 \mathrm{~kg} \mathrm{~m}^{-3}$.

The equation assumes all reagents and reactions as part of an isolated system. Because this method is easy to apply, no all-embracing representation of solution and precipitation processes is achieved. However, the cation concentration at the outlet point represents the sum of all processes in the basin and allows the calculation of a comprehensive mass balance.

\section{Results}

\subsection{Hydrogeology}

The headwater of the Schwarzaubach is fed by springs situated in the Hauptdolomit units (Fig. 2). The springs in the western part of the catchment area are located at the boundary between Hauptdolomit and kame terrace deposits (Fig. 2). The springs of the Ellmaubach are mainly encountered in the Kreuzgraben Formation or faultrelated between the Oberalm Formation and Hauptdolomit unit. The Siederbach originates in a wetland zone situated in a funnel-shaped kettle hole without any significant springs. Further downstream, the discharge increases due to the inflow of water at the intersection of the river bed with water-impermeable horizons of glacial sediments. The drainage divide in the southeastern part of the catchment runs through a Kame terrace and, hence, is morphologically not well defined. This leads to a situation where the morphological and the hydrological drainage divide do not coincide, and domains outside the morphologically-determined drainage area may contribute to the discharge of springs in this part of the catchment.
All spring waters show mean total cation concentrations between $48 \mathrm{mg} / \mathrm{l}$ and $61.5 \mathrm{mg} / \mathrm{l}$ over the entire investigation period. Depending on the weather conditions, leakage is observed in every stream of the catchment. In the headwaters, channel segments dry up in periods of low precipitation. The Ellmaubach shows remarkable leakage zones when passing the Dachsteinkalk unit. The water disappears completely for about $1 \mathrm{~km}$ and reappears downstream of the infiltration within glacial deposits (dashed part of the stream, Fig. 2). Several additional, short segments with leakage are observed along the profile in the lower reach of the Ellmaubach. In contrast, the Schwarzaubach shows short passages of leakage only at its headwaters (dashed part of the stream, Fig. 2). This behavior correlates with the bedrock-dominated parts of the stream, which consist of rocks from the Hauptdolomit unit. During dry weather conditions, the water is routed as a subsurface flow but reappears after the confluence of the three main tributaries. The catchment comprises several wetland domains and artificially-drained meadows. Both features are mainly concentrated at the kame terrace deposits, where water-impermeable clay layers control the hydrological conditions (see Fig. 2 and Fig. 3F). These wetlands are artificially drained for agricultural use by several pipes that are partly filled with calcsinter deposits at some locations (Fig. 3E). The number of drainage pipes is especially high in the glacial deposits and strongly depends on the meadows' level of moisture (Fig. 2).

\subsection{Evaluation of the gauge time series}

The rating curve (Fig. 4) is based on four water level-discharge data pairs. The first measurement was performed at the rising limb of a rainfall event, whereas the second and third measurements were performed at the falling limb of the same event (Fig. 5B, black triangles). The fourth measurement was taken independently from

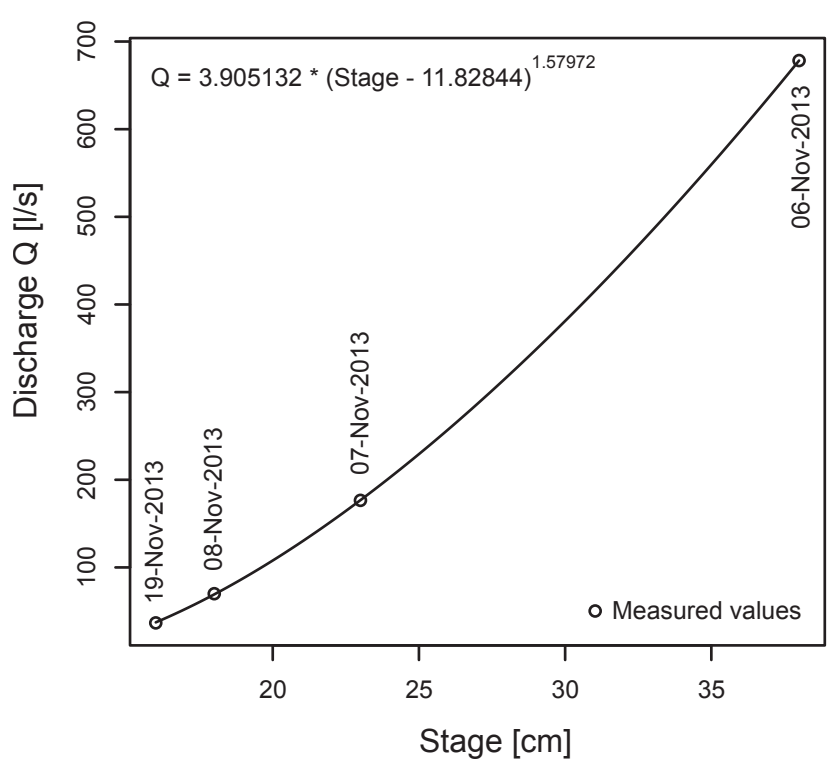

Figure 4: Rating curve of the discharge gauge at Schwarzaubach River (compare Fig. 2C). Dots are measured points interpolated by a nonlinear least square estimation. 


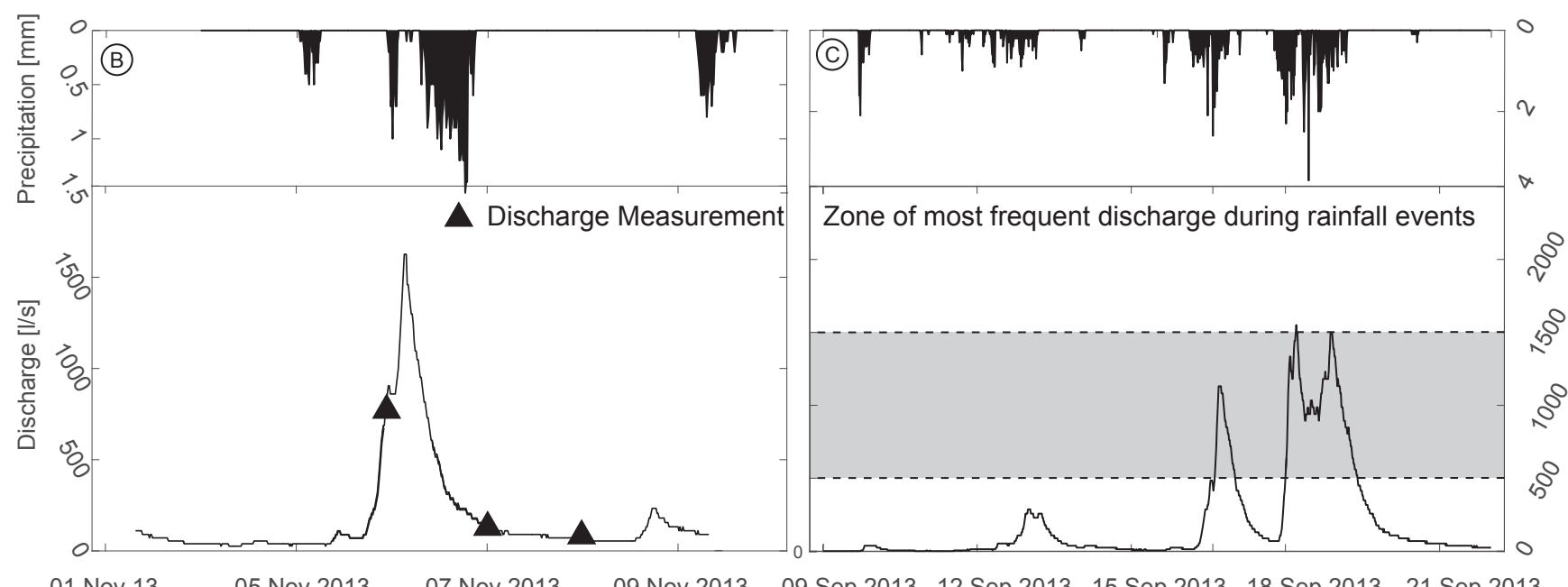

05 Nov 2013_ 07 Nov 2013 09 Nov $2013 \quad 09$ Sep 201312 Sep 201315 Sep 201318 Sep 201321 Sep 2013

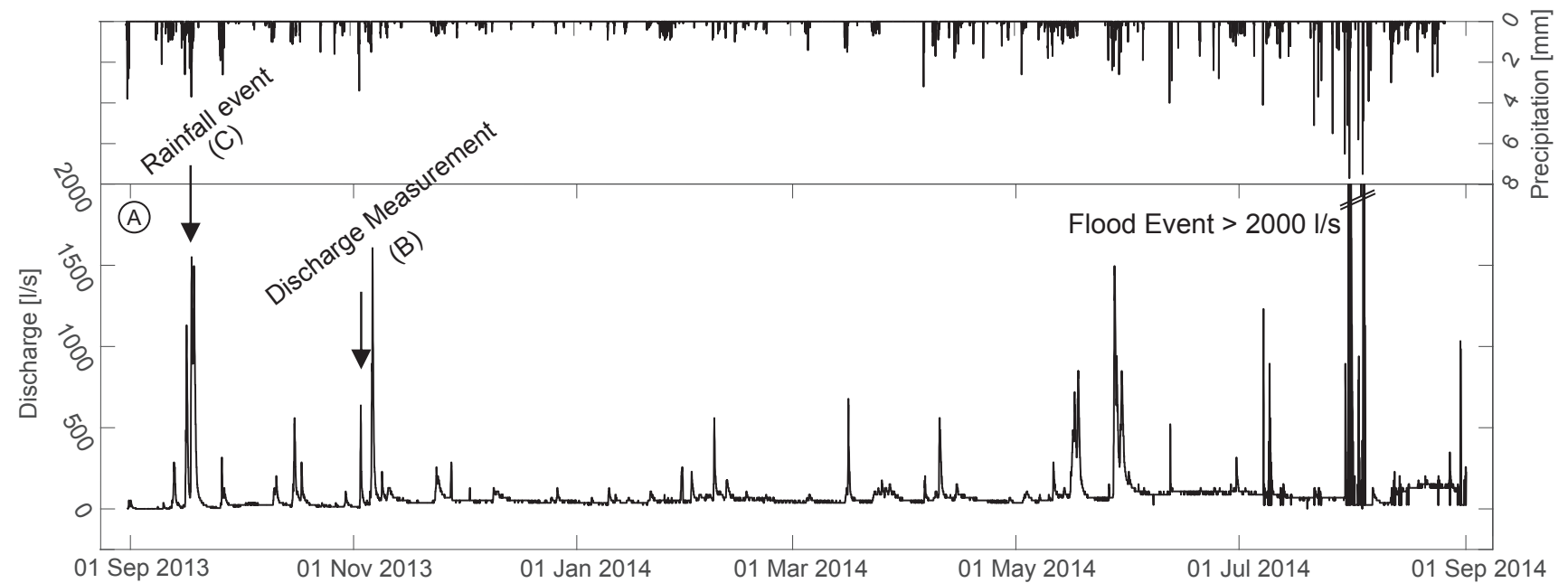

Figure 5: Time series of the discharge over the course of one year (A). Discharge regime for three out of four measurements for the calculation of the rating curve (B). Flow regime and discharge values for a typical rainfall event (C).

the rainfall event and appears to be typical for low runoff conditions and, thus, represents baseflow generated by groundwater discharge. The water level achieved from the automatic gauging station during the measuring period varies from $16-38 \mathrm{~cm}$. This leads to a variation of discharge between $37.3 \mathrm{l} / \mathrm{s}$ and $678.3 \mathrm{l} / \mathrm{s}$ (Fig. 4).

The measured water level-discharge pairs (Fig. 4, black circles) follow a power law, which is determined by a non-linear least square fit. The resulting equation has the form:

$$
Q=3.905132 \times(x-11.82844)^{1.57972}
$$

Equation 2 enables us to compute the discharge of the Schwarzaubach from the measured water level every 15 minutes. However, the resulting rating curve must be interpreted with caution, as only a limited amount of measured discharge data is available. The morphology of the streambed at the gauging station did not change due to erosion or deposition of sediments during the observation period. However, the extrapolation of the rating curve towards the peak discharge implies that the accuracy of the computed discharge decreases during storm events.
The discharge timeseries are computed for the hydrological year (09/2013-08/2014). Despite the small drainage area of the Schwarzaubach, a maximum water level of $151 \mathrm{~cm}$ was recorded during the measurement period. This water level represents a discharge value of $9503 \mathrm{l} / \mathrm{s}$. However, the discharge at the gauge exceeded values above $2000 \mathrm{l} / \mathrm{s}$ only once during the period of investigation (Fig. 5A). The statistical mode amounts to $52.36 \mathrm{l} / \mathrm{s}$, and the statistical mean value is $94.32 \mathrm{l} / \mathrm{s}$. Extreme runoff events occurred predominantly in the high summer and are caused by heavy precipitation during storm events. During the winter period, the lowest discharge values are computed, and even the highest values lie below the calculated average discharge of the measurement period. The highest discharge amounts of between $500 \mathrm{l} / \mathrm{s}$ and $1500 \mathrm{l} / \mathrm{s}$ occurred during regular rainfall events in spring and autumn (Fig. 5C).

\subsection{Distribution of the ion concentration of the surface water}

$\mathrm{Ca}^{2+}$ shows the highest concentration of the measured cations with values from 50 to $70 \mathrm{mg} / \mathrm{l}$ and is followed by $\mathrm{Mg}^{2+}$ with values of up to $20 \mathrm{mg} / \mathrm{l}$. Apart from these 
cations, only $\mathrm{Na}^{+}$and $\mathrm{K}^{+}$reach significant concentrations exceeding $0.5 \mathrm{mg} / \mathrm{l}$ (Tab. 1-3). All other cations occur in concentrations that are orders of magnitudes lower. Hence, they are regarded as negligible for the flux of dissolved mass in streams of the study area and the chemical denudation of the landscape.

Three sampling campaigns were carried out. During these campaigns, the Schwarzaubach showed runoffs of $35.8 \mathrm{l} / \mathrm{s}, 129.1 \mathrm{l} / \mathrm{s}$ and $175.0 \mathrm{l} / \mathrm{s}$, respectively (see Fig. 6 and Table 1-3). Interestingly, the cation concentration at the springs is more or less unaffected by variations in precipitation and discharge. We observe high $\mathrm{Ca}^{2+}$ concentrations at sampled springs located in the calcite-rich Kreuzgraben and Oberalm formations. In contrast, water samples from springs of the dolomitic Hauptdolomit unit mainly show an increase in $\mathrm{Mg}^{2+}$ concentrations. In general, the concentration increases downstream but varies strongly for the different sub-catchments towards the outlet (Fig. 6).

Three different types of sub-basins can be distinguished in the study area. The first type comprises drainage basins with no response to changing water levels. This is valid for the outlet of the Schwarzaubach (covering the whole catchment of the study area) and the watershed of the Ellmaubach, which shows constant cation concentrations for all three measurement campaigns. The concentrations at the outlets of the Schwarzaubach and Ellmaubach range between 74.0 and $76.7 \mathrm{mg} / \mathrm{l}$ for the Schwarzaubach and 77.4 and $80.9 \mathrm{mg} / \mathrm{l}$ for the
Ellmaubach (Fig. 6). The second type describes streams that show dilution effects during high water levels and enrichment of cations during low water levels. This is only observed in the Siederbach basin during our measurement campaigns. Consequently, the Siederbach is characterized by the largest variations in dissolved load. The amounts range from 79.3 to $107.0 \mathrm{mg} / \mathrm{l}$ total cation concentration for high and low run-off conditions, respectively (Fig. 6), and show a significant dilution effect for water high-stands. The third type defines streams in which high cation concentrations are observed during high and low water levels, and low cation values are observed for mean-flow conditions. This observation is valid for the upstream part of the Schwarzaubach basin (upstream of the gauge) with a variation between $74.7 \mathrm{mg} / \mathrm{l}$ for mean-water conditions and $86.6 \mathrm{mg} / \mathrm{l}$ for high-water conditions and the small Katzenbach basin with a variation between $67.9 \mathrm{mg} / \mathrm{l}$ for mean-water conditions and $90.9 \mathrm{mg} / \mathrm{l}$ for high water levels (Fig. 6).

For all samples, the in-situ values of temperature, $\mathrm{pH}$-value and conductivity are ascertained (Tabs. 1-3). The values range between $3-8^{\circ} \mathrm{C}$ and $7.6-8.7 \mathrm{pH}$ for the February and May campaigns and $8.2-9.6^{\circ} \mathrm{C}$ and 8.3-9.0 $\mathrm{pH}$ for the October campaign. The electric conductivity of the streams is between 238 and $523 \mu \mathrm{S} / \mathrm{cm}$ and depends on the sampled sub-basin, discharge conditions, weather conditions and season. During wet periods, characterized by high amounts of surficial runoff and short retention periods, the conductivity profiles are less

\begin{tabular}{|c|c|c|c|c|c|c|c|c|c|c|c|c|c|c|}
\hline $\begin{array}{l}\text { Sample } \\
{[\mu \mathrm{g} / \mathrm{l}]}\end{array}$ & Total & Li & $\mathrm{Na}$ & Mg & $\mathbf{K}$ & $\mathrm{Ca}$ & Mn & $\mathrm{Fe}$ & $\mathbf{R b}$ & Sr & Cs & $\mathrm{Ba}$ & $\mathrm{Pb}$ & $\mathbf{U}$ \\
\hline ELB & 77796 & 0.81 & 1412 & 15594 & 705 & 59943 & 0.16 & 1.45 & 0.41 & 119 & $<0.00$ & 19.3 & $<0.00$ & 0.57 \\
\hline HDB & 88575 & 0.19 & 761 & 21974 & 450 & 65280 & 1.53 & 18.51 & 0.38 & 75.1 & $<0.000$ & 12.85 & 0.00 & 0.99 \\
\hline SIB & 107022 & 0.43 & 1534 & 17684 & 1996 & 85654 & 0.98 & 3.04 & 0.99 & 129.1 & $<0.000$ & 18.42 & 0.01 & 0.77 \\
\hline SWB-1 & 80600 & 0.77 & 1088 & 16639 & 859 & 61881 & 0.18 & 2.07 & 0.51 & 111.8 & $<0.000$ & 16.97 & $<0.000$ & 0.54 \\
\hline SWB-2 & 82269 & 0.92 & 1279 & 17438 & 886 & 62521 & 2.73 & 9.11 & 0.68 & 114.5 & 0.11 & 16.40 & 0.02 & 0.72 \\
\hline SWB-4 & 73426 & 0.61 & 1252 & 15048 & 576 & 56426 & 0.52 & 4.46 & 0.36 & 100.7 & $<0.000$ & 16.79 & 0.03 & 0.51 \\
\hline SWB-5 & 76821 & 0.24 & 1023 & 16620 & 448 & 58648 & 0.24 & 3.20 & 0.44 & 62.2 & 0.01 & 14.77 & 0.03 & 0.52 \\
\hline WTS-1 & 60501 & 0.45 & 1499 & 8562 & 483 & 49835 & 1.05 & 8.68 & 0.35 & 97.9 & $<0.000$ & 13.26 & 0.17 & 0.31 \\
\hline WTS-2 & 65361 & 0.47 & 2212 & 10569 & 559 & 51905 & 1.92 & 5.75 & 0.36 & 97.1 & $<0.000$ & 10.14 & 0.06 & 0.39 \\
\hline Sample & pH & $\mathbf{T}\left[{ }^{\circ} \mathbf{C}\right]$ & $\begin{array}{l}\text { Cond. } \\
{[\mu \mathrm{S} / \mathrm{cm}]}\end{array}$ & $X[\mathrm{~m}]$ & $Y[m]$ & & & & & & & & & \\
\hline HDB & 8.7 & 3.8 & 434 & 438429 & 295010 & & & & & & & & & \\
\hline SIB & 8.5 & 5.6 & 523 & 438924 & 294943 & & & & & & & & & \\
\hline SWB-1 & 7.9 & 6.2 & 412 & 440620 & 294195 & & & & & & & & & \\
\hline SWB-2 & 8.4 & 6.1 & 410 & 438920 & 294908 & & & & & & & & & \\
\hline SWB-3 & 8.6 & 7.6 & 380 & 438390 & 295025 & & & & & & & & & \\
\hline SWB-4 & 8.2 & 8.0 & 378 & 438575 & 294991 & & & & & & & & & \\
\hline SWB-5 & 8.5 & 6.8 & 390 & 438461 & 291929 & & & & & & & & & \\
\hline WTS-1 & 8.4 & 5.0 & 304 & 438755 & 291406 & & & & & & & & & \\
\hline WTS-2 & 8.4 & 6.4 & 330 & 438648 & 291347 & & & & & & & & & \\
\hline
\end{tabular}

$\mathrm{pH}=\mathrm{pH}$-value. $\mathrm{T}=$ Temperature. LF. Cond. = Conductivity. $\mathrm{X}=\mathrm{X}$-Coordinate. $\mathrm{Y}=\mathrm{Y}$-Coordinate (BMN-M31)

Table 1: Results of the first measurement campaign 26-Feb-2014 


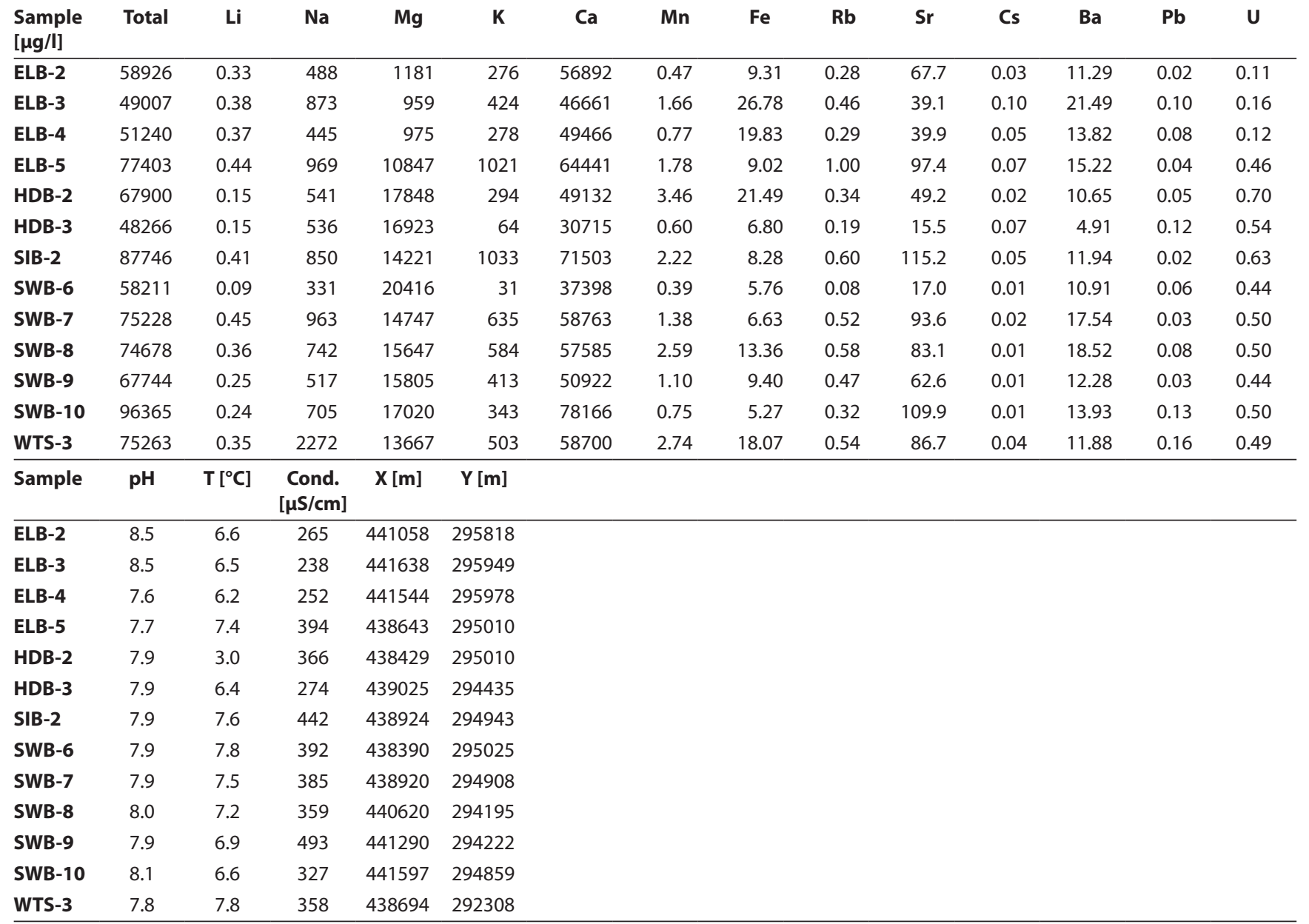

$\mathrm{pH}=\mathrm{pH}$-value. $\mathrm{T}=$ Temperature. LF. Cond. = Conductivity. $\mathrm{X}=\mathrm{X}$-Coordinate. $\mathrm{Y}=\mathrm{Y}$-Coordinate (BMN-M31)

Table 2: Results of the second measurement campaign 14-May-2014

\begin{tabular}{|c|c|c|c|c|c|c|c|c|c|c|c|c|c|c|}
\hline $\begin{array}{l}\text { Sample } \\
{[\mu \mathrm{g} / \mathrm{l}]}\end{array}$ & Total & Li & $\mathrm{Na}$ & Mg & $\mathbf{K}$ & $\mathrm{Ca}$ & Mn & $\mathrm{Fe}$ & $\mathbf{R b}$ & Sr & Cs & $\mathrm{Ba}$ & $\mathbf{P b}$ & $\mathbf{U}$ \\
\hline ELB-6 & 80921 & 0.91 & 1449 & 14787 & 595 & 63935 & 0.89 & 6.7 & 0.41 & 122 & 0.020 & 23 & 0.07 & 0.59 \\
\hline ELB-7 & 61751 & 0.81 & 1033 & 1968 & 259 & 58350 & 0.38 & 8.9 & 0.24 & 110 & 0.007 & 21 & 0.07 & 0.17 \\
\hline SWB-14 & 76670 & 0.71 & 1243 & 14034 & 538 & 60724 & 0.65 & 3.7 & 0.36 & 107 & 0.006 & 18 & 0.04 & 0.53 \\
\hline SIB-3 & 79302 & 0.81 & 1294 & 13188 & 786 & 63882 & 0.66 & 4.1 & 0.44 & 122 & 0.003 & 23 & 0.03 & 0.49 \\
\hline ELB-8 & 71842 & 0.71 & 1044 & 1832 & 290 & 68552 & 0.59 & 5.8 & 0.25 & 94 & 0.001 & 22 & 0.07 & 0.17 \\
\hline SWB-11 & 61535 & 0.12 & 280 & 20145 & 16 & 41063 & 0.22 & 3.9 & 0.10 & 18 & 0.005 & 7.6 & 0.05 & 0.51 \\
\hline SWB-13 & 86638 & 0.74 & 1131 & 15674 & 784 & 68895 & 3.07 & 6.7 & 0.44 & 119 & 0.004 & 23 & 0.08 & 0.55 \\
\hline HDB-4 & 90863 & 0.28 & 572 & 20426 & 352 & 69404 & 1.54 & 15.2 & 0.48 & 73 & 0.009 & 17 & 0.05 & 0.84 \\
\hline Sample & pH & $\mathbf{T}\left[{ }^{\circ} \mathbf{C}\right]$ & $\begin{array}{c}\text { Cond. } \\
{[\mu S / \mathrm{cm}]}\end{array}$ & $X[\mathrm{~m}]$ & $Y[\mathrm{~m}]$ & & & & & & & & & \\
\hline ELB-6 & 8.6 & 9.6 & 443 & 438643 & 295010 & & & & & & & & & \\
\hline SWB-14 & 8.3 & 8.2 & 368 & 441058 & 295818 & & & & & & & & & \\
\hline SIB-3 & 8.9 & 9.3 & 489 & 438429 & 295010 & & & & & & & & & \\
\hline ELB-8 & 8.7 & 8.3 & 437 & 438924 & 294943 & & & & & & & & & \\
\hline SWB-12 & 9.0 & 9.2 & 342 & 441597 & 294859 & & & & & & & & & \\
\hline SWB-11 & 8.7 & 8.2 & 454 & 440620 & 294195 & & & & & & & & & \\
\hline SWB-13 & 8.8 & 8.2 & 460 & 438920 & 294908 & & & & & & & & & \\
\hline HDB-4 & 8.5 & 8.9 & 422 & 438390 & 295025 & & & & & & & & & \\
\hline
\end{tabular}

$\mathrm{pH}=\mathrm{pH}$-value. $\mathrm{T}=$ Temperature. $\mathrm{LF}$. Cond. = Conductivity. $\mathrm{X}=\mathrm{X}$-Coordinate. $\mathrm{Y}=\mathrm{Y}$-Coordinate (BMN-M31)

Table 3: Results of the third measurement campaign 30/31-Oct-2014 


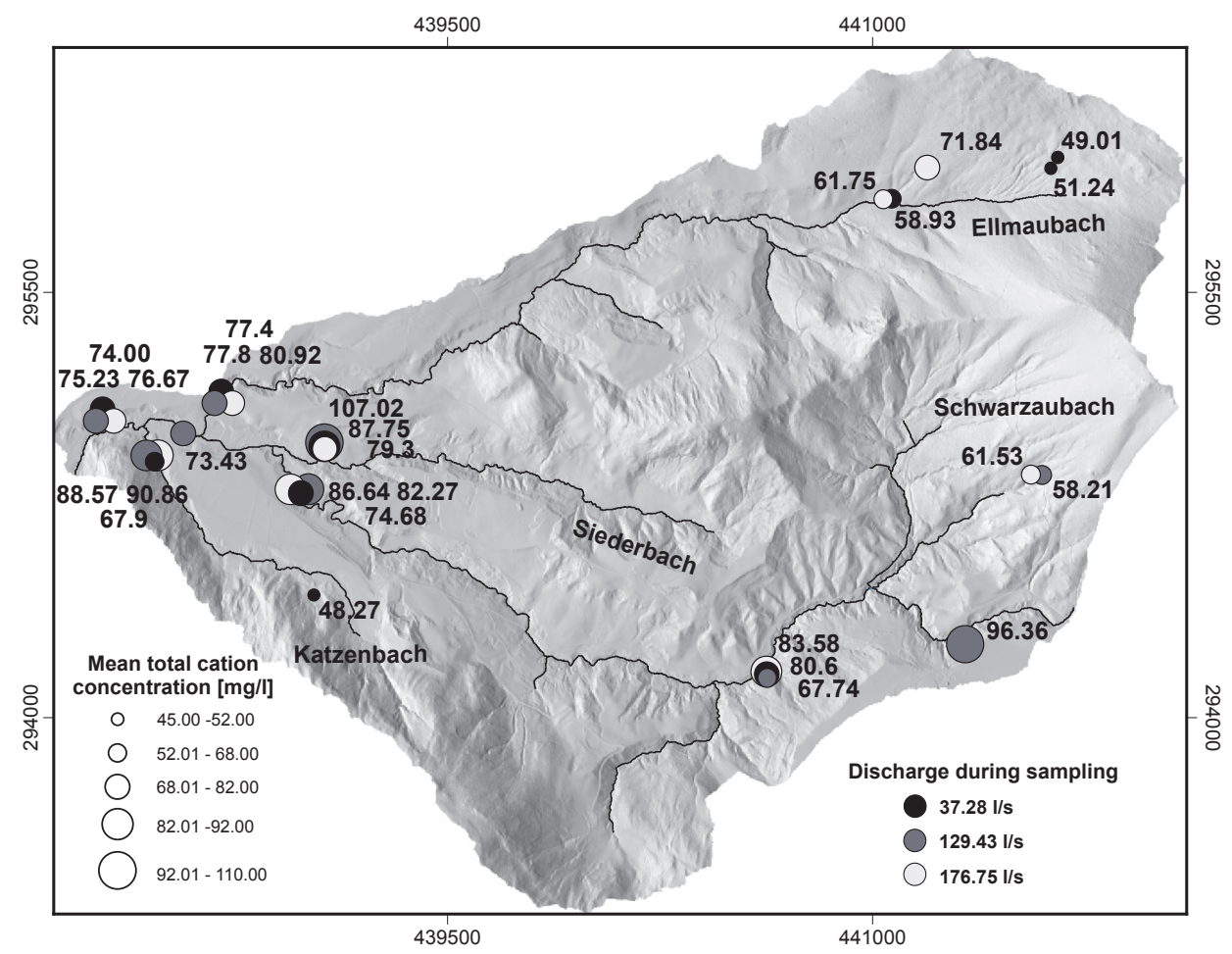

Figure 6: Mean total cation concentrations ( $\mathrm{mg} / \mathrm{l})$ for three different measurement campaigns and flow regimes. The size of the dots shows the sum of the cation concentration in the sample (For sample name compare Fig. 1). The color of the dots gives the measurement campaign and discharge values during the sampling.
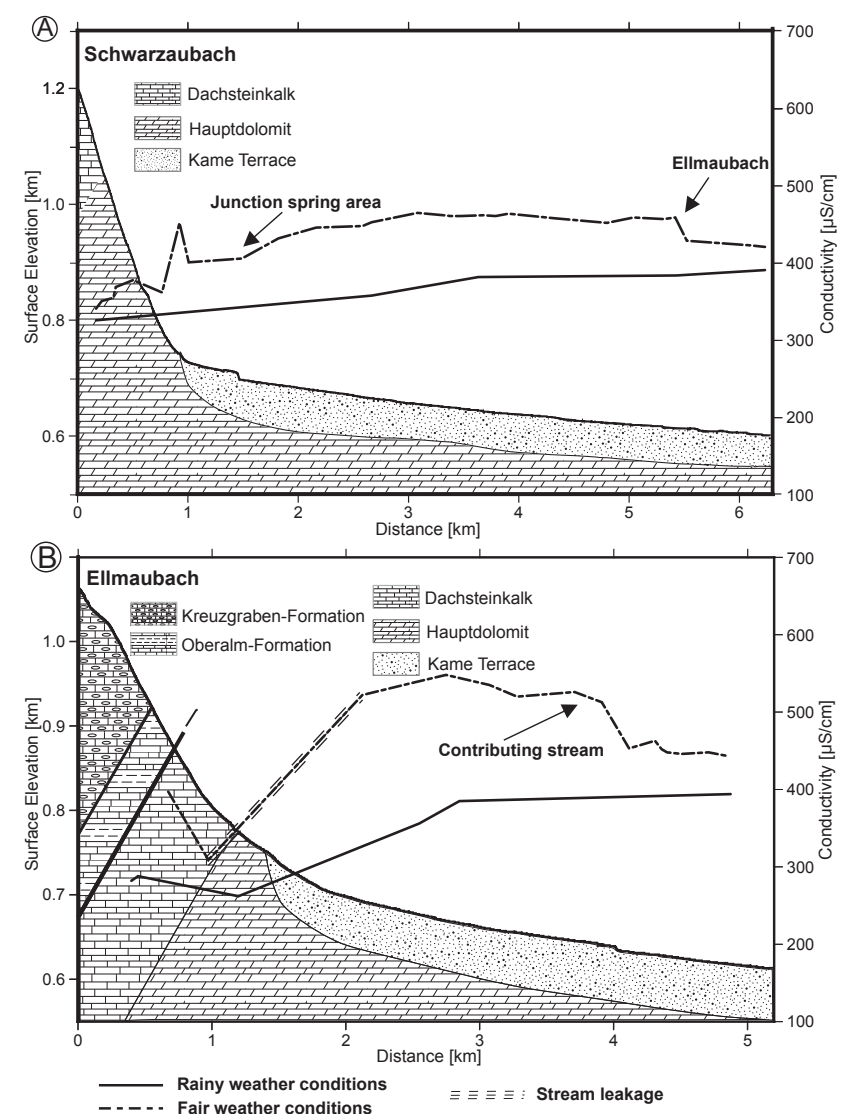

Figure 7: Longitudinal stream profiles combining the lithology and variance of the specific electrical conductivity along Schwarzaubach (A) and Ellmaubach (B). Black dashed lines are values obtained for fair weather conditions. Solid lines are values obtained for rainy weather conditions. Rainy weather conditions show a linear conductivity trend. Fair weather conditions show more spikes and leakage effects. spatially variable and show lower conductivity values compared to profiles measured during stable weather periods with low precipitation input (Fig. 7A, B). The profiles collected during wet conditions generally show increasing conductivity values downstream but do not reach their maximum at the outlet. This observation is consistent with the ion concentrations. The conductivity increases during the passage of glacial deposits. The leakage passage of the Ellmaubach also leads to an increase in conductivity. The junction of the Ellmaubach and the Schwarzaubach causes a decline of conductivity at the Schwarzaubach basin (Fig. 7A). The Ellmaubach basin shows an increase in conductivity after the leakage passage along the profile (Fig. 7B).

\subsection{Mass balance of the drainage basin}

The integrated annual runoff at the gauge adds up to $2.97 \times 10^{6} \mathrm{~m}^{3}$ of water for a drainage area of $2.97 \mathrm{~km}^{2}$, which equals $1000 \mathrm{~mm} / \mathrm{a}$. This is well in line with the average precipitation of approx. $1600 \mathrm{~mm} / \mathrm{a}$ measured at the nearby hydrological station of Hintersee. The discrepancy results mainly from evapotranspiration effects and partly from groundwater recharge. The separation of the total flow gives $1.77 \times 10^{6} \mathrm{~m}^{3}$ for the baseflow-dominated and $1.2 \times 10^{6} \mathrm{~m}^{3}$ for the stormflow-dominated discharge.

We suppose that water samples of the first and last field measurement campaign, which feature discharge values of $37.8 \mathrm{l} / \mathrm{s}$ and $176.7 \mathrm{l} / \mathrm{s}$ at the gauging station of the Schwarzaubach, are representative for the baseflow-dominated cation concentration of the catchment $(82.3 \mathrm{mg} / \mathrm{l}$ and $86.6 \mathrm{mg} / \mathrm{l}$ total mean concentration at the discharge gauge, Tab. 1 and 3). In contrast, samples from 14-May-2014 are biased by high inflow of surface runoff due to a heavy precipitation event $(75.2 \mathrm{mg} / \mathrm{l}$ total mean concentration at the discharge gauge, compare Tab. 2). We regard this concentration as representative for stormflow-dominated discharge conditions, as the high amount of incoming fresh-water led to dilution effects within the cation concentration during this measurement period. For the comparison with denudation rates derived from the total flow (no distinction between baseflow and stormflow), the mean values of all measurements are used $\left(\mathrm{Ca}^{+}=63.39 \mathrm{mg} / \mathrm{l}, \mathrm{Mg}^{+}=15.95 \mathrm{mg} / \mathrm{l}\right)$. The cation concentrations of baseflow-dominated conditions 
differ only slightly from the mean values of all measurements $\left(\mathrm{Ca}^{2+}=65.71 \mathrm{mg} / \mathrm{l}, \mathrm{Mg}^{2+}=16.56 \mathrm{mg} / \mathrm{l}\right)$. In contrast, the cation concentrations of stormflow-dominated conditions are considerably lower $\left(\mathrm{Ca}^{2+}=58.76 \mathrm{mg} / \mathrm{l}\right.$, $\left.\mathrm{Mg}^{2+}=14.75 \mathrm{mg} / \mathrm{l}\right)$.

For the calculation of denudation rates, we assume that the $\mathrm{Ca}^{2+}$ and $\mathrm{Mg}^{2+}$ concentrations of the measured water samples originate exclusively from the dissolution of carbonates such as $\mathrm{CaCO}_{3}$ and $\mathrm{CaMg}\left(\mathrm{CO}_{3}\right)_{2}$. The $\mathrm{CaMg}\left(\mathrm{CO}_{3}\right)_{2}$ amount corresponds to the equivalent value of the theoretical composition of the dolomite end member, as the actual ratio of limestone and dolomite weathering is unknown.

We obtain a catchment-wide denudation rate of $0.094 \mathrm{~mm} / \mathrm{a}$ (94 mm/1000a) without considering a separated hydrograph. However, considering different runoff conditions by separating the discharge into baseflow and stormflow conditions, we get denudation rates of $0.057 \mathrm{~mm} / \mathrm{a}$ (57 mm/1000a) for baseflow-dominated runoff conditions and $0.035 \mathrm{~mm} / \mathrm{a}$ (35 mm/1000a) for stormflow-dominated runoff conditions. By integrating the denudation rates of baseflow and stormflow runoff regimes, we obtain an annual denudation rate of $0.092 \mathrm{~mm} / \mathrm{a}$ (92 mm/1000a).

\section{Discussion}

Our study reveals conclusive chemical denudation rates for calculations based on a separated hydrograph, as well as based on the unseparated total discharge. The proportion of chemical denudation on the redistribution of (rock) mass and landscape evolution is mainly controlled by the lithology and the amount of precipitation (Meybeck, 1987; Summerfield and Hulton, 1994; White and Blum, 1995). The dominance of carbonate-bearing rocks and the occurrence of high precipitation rates at the Schwarzaubach catchment suggest that chemical denudation contributes significantly to the total denudation rate.

\subsection{Chemical variations of the surface waters}

As reported by previous studies (e.g. Shuster and White, 1971; Ravbar et al., 2011) variations in the cation composition of spring waters are most likely related to the predominant lithology. This is well in line with the observations made in this study. The distribution of the ion concentration in the surface runoff of the catchment is also influenced by further parameters and processes: besides the $\mathrm{pH}$-value and the temperature, the retention time of the groundwater influences the possible amount of rock solution. In turn, the retention time is, among other factors, controlled by the lithological characteristic of the aquifer. This affects the mixing of the groundwater and surface waters and, hence, the distribution and variation of the ion concentration in the surface waters of the drainage basin (e.g. Moore et al., 2009).

In the simplest case, it is expected that an increasing amount of precipitation also leads to an increase in the direct runoff component (Beven, 2011) and, subsequently, to dilution effects in the outflow of the aquifer (Hay, 1998). In consequence, the cation concentration decreases with increasing discharge values (e.g. Johnson et al., 1969 and references therein). This is shown for the Siederbach catchment and can be directly related to the rapid water flow through the glacial deposits. We assume that the highest cation-concentration during mean-water runoff is related to the high water solubility of unconsolidated sediment. We observe that this effect breaks down for high flow velocities that are characteristic of high runoff regimes.

Even though the majority of chemical variations in streams is attributed to the predominant discharge conditions, a simple relationship between discharge and chemical concentration is only rarely observed (Evans and Davies, 1998 and references therein). The Schwarzaubach and Ellmaubach catchments, for instance, show no significant changes in the ion concentration for different runoff conditions. We assume that a high contribution of aquifer water to the runoff component buffers short-term precipitation events in these catchments. This results in stable cation concentrations over time.

In contrast, high ion concentrations are observed for high water and low ion concentrations for low water runoff conditions in the upstream parts of the Schwarzaubach and the Katzenbach catchments. These sections of the streams flow mainly through Hauptdolomit units and have short leakage passages, which indicate karstification processes. Karstification in dolomites allows a decelerated outflow out of the aquifer due to a finer jointing of the rocks and, therefore, a longer retention period of the water (Pavuza and Traindl, 1983). We thus relate the observed distribution of cation concentrations to a "syphon" effect of a karst dominated aquifer. Grasso and Jeannin (2002) describe such a process, where the water from rainfall events reaches the saturated zone and generates an increase in the aquifer pressure. The increase, in turn, leads to the rise of discharge generated by springs and, thus, to the rapid expelling of the aquifer water (Grasso and Jeannin, 2002; Ford and Williams, 2013). As a result, the surface water is enriched with $\mathrm{Mg}^{2+}$ and $\mathrm{Ca}^{2+}$, and no dilution effects are observed for the first high water wave after a precipitation event.

\subsection{Uncertainty of measurement method}

The distribution of the cation concentration shows that variations in lithology lead to a great variation in the runoff behavior, even in small catchments. However, the spatial analysis of the hydrochemical data provides additional insight into the accuracy of the calculated chemical denudation rate. In particular, the constant cation concentrations at the outlet are unaffected by varying runoff conditions and karstification and suggest a certain robustness of this method. Additionally, the separation of the hydrograph shows that almost $2 / 3$ of the chemical denudation is related to baseflow-dominated runoff and only $1 / 3$ is related to stormflow-generated runoff. This 
indicates the importance of steady-state flow conditions and related mean cation concentrations for the calculation of chemical denudation rates.

Nevertheless, uncertainties have to be taken into account for an evaluation of the achieved denudation rates. The rating curve with only four measurements is rather under-sampled for high water levels and, hence, for discharge values exceeding $700 \mathrm{l} / \mathrm{s}$. However, discharge exceeding $700 \mathrm{l} / \mathrm{s}$ accounts for only approx. $20 \%$ of the total discharge volume. Furthermore, we assume that the estimation of the rating curve is solid, as no significant changes in the bedrock and slopes of the measuring gauge were recognized during the course of the year.

\subsection{Evaluation of the chemical denudation rates}

The chemical denudation rate of $94 \mathrm{~mm} / 1000 \mathrm{a}$ documented here is well in line with chemical denudation rates reported in the literature. Hinderer et al. (2013) compiled chemical denudation and mechanical denudation for the European Alps averaged over the NCA. The total denudation rate adds up to $347 \mathrm{~mm} / 1000 \mathrm{a}$, where $100 \mathrm{~mm} / 1000 \mathrm{a}$ are attributed to chemical denudation. Several studies from investigation sites comparable to our study area have also calculated chemical denudation rates by measuring the dissolved load. Bakalowicz (1979) obtained values between $48 \mathrm{~mm} / 1000 \mathrm{a}$ and $89 \mathrm{~mm} / 1000$ a for a series of karst-dominated catchments of the French Pyrenees. Gams et al. (2004) calculated $60 \mathrm{~mm} / 1000 \mathrm{a}$ of chemical denudation for a catchment in Slovenia. Gunn (1981) obtained 69 mm/1000a of chemical denudation for an area in New Zealand. The catchments investigated by Gams et al. (2004) and Gunn (1981) are characterized by annual precipitation of $1500 \mathrm{~mm} / \mathrm{a}$ and $1450 \mathrm{~mm} / \mathrm{a}$, respectively, and hence show precipitation and runoff conditions similar to those in our study area. In a further study in the NCA (Hochschwab Karst Massif), Plan (2005) calculated a denudation rate of $95 \mathrm{~mm} / 1000$ a for a precipitation rate of $2100 \mathrm{~mm} / \mathrm{a}$. Even though the precipitation rate is significantly higher, the denudation rate is well in line with that determined in our study. Kunaver (1979) reported a chemical denudation of $94 \mathrm{~mm} / 1000 \mathrm{a}$ for a precipitation rate of extraordinary $3000 \mathrm{~mm} / \mathrm{a}$ in the Slovenian Alps. Despite this being double the amount of precipitation compared to our study area, the denudation rate is in the range of that of the Schwarzaubach basin. This suggests that dissolution of carbonates in karstified areas is rather controlled by the retention time than by the precipitation rate. This is particularly applicable when the precipitation rate exceeds a certain limit, where the retention time seems to be negatively correlated with the precipitation rate and the effect of dilution becomes dominant. The degree of karstification of the limestone-dominated Hochschwab massif and the Slovenian Alps is undoubtedly greater than in our study area. We suppose that this is primarily related to diverse bedrock properties - the karstification in the Schwarzaubach catchment occurs predominantly in dolomitic bedrock. We suggest that diverse bedrock properties cause variations in the retention time, control the solution of rocks and, hence, the ion concentration of the water. However, the need to also consider exogenous effects, e.g. precipitation, climatic variability or topographic relief, is obvious for a valid comparison of different denudation rates (e.g. Pulina, 1971; Gams, 1972; Bakalowicz, 1992).

\section{Conclusion}

We derived a catchment-wide chemical denudation rate of a representative alpine catchment of the NCA, based on the computation of average cation concentrations of the surface water and the annual discharge. We propose that dissolution of carbonates and, hence, chemical denudation significantly contributes to the overall erosion rate of carbonate-dominated catchments and, therefore, plays a dominant role in landscape evolution in the NCA. We conclude that:

- Measuring discharge time series and the cation concentration of surface water in different runoff regimes (i.e. baseflow and stormflow runoff regime) allow a reliable computation of chemical denudation rates in carbonate-dominated catchments.

- The cation-concentration of the surface-water is controlled by precipitation events and their temporal succession and reflects complex dissolution processes in diverse substrates. This is particularly applicable to bedrock prone to karstification.

- The amount of chemical denudation generated by baseflow and stormflow contributes roughly $2 / 3$ and $1 / 3$ to the total denudation, respectively.

- Chemicalerosion is a principalagentin redistributing mass as a dissolved load in carbonate-dominated catchments. There, chemical erosion contributes significantly to the total amount of denudation and, hence, influences the long term landscape evolution.

In this study, we applied a simple but reliable method to determine chemical denudation rates in a small torrential catchment. The calculated denudation rates are well in line with denudation rates reported by studies investigating catchments with similar lithologic and climatic characteristics. The simplicity of our approach and the availability of a large number of automatic gauging stations demonstrate its great potential for monitoring temporal and spatial variations in chemical denudation in the NCA.

\section{Acknowledgements}

We would like to thank Matthias Hinderer and an anonymous reviewer who strongly helped to improve this manuscript. Part of the research was funded by the Austrian Science Fund (FWF) through the Doctoral College GIScience at the University of Salzburg (DK W 1237-N23). 


\section{References}

Bakalowicz, M., 1979. Contribution de la géochimie des eaux à la connaissance de l'aquifère karstique et de la karstification. Doctoral Thesis, Université Pierre et Marie Curie, Paris, France, 269 pp.

Bakalowicz, M., 1992. Géochimie des eaux et flux de matières dissoutes, I'approche objective du rôle du climat dans la karstogenèse. Karst et évolution climatique, Presses Universitaires de Bordeaux, pp. 61-74.

Beven, K. J., 2011. Rainfall-Runoff Modelling: The Primer. John Wiley \& Sons, West Sussex, 488 pp.

Corbel, J., 1959. Erosion en terrain calcaire (vitesse d'érosion et morphologie). Annales de geographie, 68/366, 97-120.

Cucchi, F., Forti, F., Furlani, S., 2006. Lowering rates on limestone along the Western Istrian shoreline and the Gulf of Trieste. Geografia Fisica e Dinamica Quaternaria, 29/1, 61-69.

Egger, H., and van Husen, D., 2009. Erläuterungen zu Blatt 64 Strasswalchen. Geologische Karte der Republik Österreich (1:50.000). Geologische Bundesanstalt, Wien, 87 pp.

Evans, C., Davies, T. D., 1998. Causes of concentration/discharge hysteresis and its potential as a tool for analysis of episode hydrochemistry. Water Resources Research, 34/1, 129-137. https://doi.org/10.1029/97wr01881

Ford, D., Williams, P. D., 2013. Karst Hydrogeology and Geomorphology. John Wiley \& Sons, West Sussex, 576 pp.

Gabrovšek, F., 2009. On concepts and methods for the estimation of dissolutional denudation rates in karst areas. Geomorphology, 106/1-2, 9-14. https://doi. org/10.1016/j.geomorph.2008.09.008

Gams, I., 1972. Effect of runoff on corrosion intensity in the Northwestern Dinaric karst. Transactions of the Cave Research Group, 14/2, 78-83.

Gams, I., Knez, M., Sajko, I., Drole, F., Huzjan, M. Ž., 2004. Kras v Sloveniji v prostoru in času. ZRC Publishing, Ljublijana, 293 pp.

Grasso, D. A., Jeannin, P. Y., 2002. A global experimental system approach of karst springs' hydrographs and chemographs. Ground Water, 40/6, 608-617. https://doi. org/10.1111/j.1745-6584.2002.tb02547.x

Gunn, J., 1981. Limestone Solution Rates and Processes in the Waitomo District, New-Zealand. Earth Surface Processes and Landforms, 6/5, 427-445. https://doi. org/10.1002/esp.3290060504

Hay, W. W., 1998. Detrital sediment fluxes from continents to oceans. Chemical Geology, 145/3-4, 287-323. https://doi.org/10.1016/S0009-2541(97)00149-6

High, C., Hanna, F. K., 1970. Method for the direct measurement of erosion on rock surfaces. British Geomorphological Research Group Technical Bulletin. British Geomorphological Research Group, Norwich, 5, 1-24.

Hinderer, M., Kastowski, M., Kamelger, A., Bartolini, C., Schlunegger, F., 2013. River loads and modern denudation of the Alps-A review. Earth-Science Reviews, 118, 11-44. https://doi.org/10.1016/j.earscirev.2013.01.001
Johnson, N. M., Likens, G. E., Bormann, F., Fisher, D., Pierce, R., 1969. A working model for the variation in stream water chemistry at the Hubbard Brook Experimental Forest, New Hampshire. Water Resources Research, 5/6, 1353-1363. https://doi.org/10.1029/ WR005i006p01353

Kunaver, J., 1979. Some experiences in measuring the surface karst denudation in high alpine environment. Actes du Symposium international sur l'érosion karstique, Aix en Provence, pp. 75-85.

Lauritzen, S. E., 1990. Autogenic and allogenic denudation in carbonate karst by the multiple basin method: An Example from Svartisen, North Norway. Earth Surface Processes and Landforms, 15/2, 157-167. https://doi. org/10.1002/esp.3290150206

Meybeck, M., 1987. Global chemical weathering of surficial rocks estimated from river dissolved loads. American Journal of Science, 287/5, 401-428. https:// doi.org/10.2475/ajs.287.5.401

Moore, P. J., Martin, J. B., Screaton, E. J., 2009. Geochemical and statistical evidence of recharge, mixing, and controls on spring discharge in an eogenetic karst aquifer. Journal of Hydrology, 376/3-4, 443-455. https://doi. org/10.1016/j.jhydrol.2009.07.052

Morche, D., Schmidt, K. H., 2012. Sediment transport in an alpine river before and after a dambreak flood event. Earth Surface Processes and Landforms, 37/3, 347-353. https://doi.org/10.1002/esp.2263

Neteler, M., Bowman, M. H., Landa, M., Metz, M., 2012. GRASS GIS: A multi-purpose open source GIS. Environmental Modelling \& Software, 31, 124-130. https://doi.org/10.1016/j.envsoft.2011.11.014

Norton, K. P., von Blanckenburg, F., DiBiase, R., Schlunegger, F., Kubik, P. W., 2011. Cosmogenic 10Be-derived denudation rates of the Eastern and Southern European Alps. International Journal of Earth Sciences, 100/5, 1163-1179. https://doi.org/10.1007/ s00531-010-0626-y

O'Callaghan, J. F., Mark, D. M., 1984. The extraction of drainage networks from digital elevation data. Computer Vision, Graphics, and Image Processing, 27/2, 247. https://doi.org/10.1016/S0734-189X(84) 80047-X

Pavuza, R., Traindl, H., 1983. Über Dolomitkarst in Österreich. Die Höhle, 34/1, 15-25.

Pettyjohn, W. A., Henning, R., 1979. Preliminary estimate of ground-water recharge rates, related streamflow and water quality in Ohio. Project Completion Report, 552. Ohio State University Water Resources Center, Columbus, $323 \mathrm{pp}$.

Plan, L., 2005. Factors controlling carbonate dissolution rates quantified in a field test in the Austrian alps. Geomorphology, 68/3-4, 201-212. https://doi. org/10.1016/j.geomorph.2004.11.014

Pulina, M., 1971. Observations on the chemical denudation of some karst areas of Europe and Asia. Studia geomorphologica Carpatho-Balcanica, 5, 79-91. 
Rantz, S. E., 1982. Measurement and computation of streamflow: Measurement of stage and discharge. US Geologcial Survey, Water Supply Paper, 2175, 284 pp.

Ravbar, N., Engelhardt, I., Goldscheider, N., 2011. Anomalous behaviour of specific electrical conductivity at a karst spring induced by variable catchment boundaries: the case of the Podstenjšek spring, Slovenia. Hydrological Processes, 25/13, 2130-2140. https://doi. org/10.1002/hyp.7966

Robl, J., Hergarten, S., Stüwe, K., 2008. Morphological analysis of the drainage system in the Eastern Alps. Tectonophysics, 460/1-4, 263-277. https://doi.org/10.1016/j. tecto.2008.08.024

Sagis, 2014. Digitales Höhenmodell, 1 m Raster. Land Salzburg.

Salcher, B. C., Hinsch, R., Wagreich, M., 2010. High-resolution mapping of glacial landforms in the North Alpine Foreland, Austria. Geomorphology, 122/3-4, 283-293. https://doi.org/10.1016/j.geomorph.2009.09.037

Shuster, E. T., White, W. B., 1971. Seasonal fluctuations in the chemistry of lime-stone springs: A possible means for characterizing carbonate aquifers. Journal of Hydrology, 14/2, 93-128. https://doi. org/10.1016/0022-1694(71)90001-1

Stone, J. O. H., Evans, J. M., Fifield, L. K., Allan, G. L., Cresswell, R. G., 1998. Cosmogenic Chlorine-36
Production in Calcite by Muons. Geochimica et Cosmochimica Acta, 62/3, 433-454. https://doi.org/10.1016/ S0016-7037(97)00369-4

Summerfield, M., Hulton, N., 1994. Natural controls of fluvial denudation rates in major world drainage basins. Journal of Geophysical Research: Solid Earth, 99/B7, 13871-13883. https://doi.org/10.1029/ 94JB00715

Trudgill, S. T., 1975. Measurement of erosional weight loss of rock tablets. British Geomorphological Research Group Technical Bulletin, British Geomorphological Research Group, Norwich, 17, 13-20.

White, A. F., and Blum, A. E., 1995. Effects of climate on chemical_ weathering in watersheds. Geochimica et Cosmochimica Acta, 59/9, 1729-1747. https://doi. org/10.1016/0016-7037(95)00078-E

Wittmann, H., von Blanckenburg, F., Kruesmann, T., Norton, K. P., Kubik, P. W., 2007. Relation between rock uplift and denudation from cosmogenic nuclides in river sediment in the Central Alps of Switzerland. Journal of Geophysical Research-Earth Surface, 112/F4. https://doi.org/10.1029/2006jf000729

ZAMG, 2017. Jährlicher Wetterrückblick. Zentralanstalt für Meteorologie und Geodynamik, Vienna. http:// www.zamg.ac.at/cms/de/klima/klima-aktuell/jahresrueckblick (accessed on 28 February 2018).

4) Austrian Service for Torrent and Avalanche Control, Section Salzburg, Bergheimer Straße 57, 5021 Salzburg, Austria;

5) Institute of Chemistry, University of Graz, Universitätsplatz 1, 8010 Graz, Austria;

*) Corresponding author: georg.trost@sbg.ac.at 